\title{
Sandu Frunză: „Advertising and Administration under the Pressure of Ethics" - Book review
}

\author{
Ştefan Vlăduţescu \\ University of Craiova, 13 A. I. Cuza Street, 200585, Craiova, Romania \\ E-mail address: stefan.vladutescu@yahoo.com
}

\section{ABSTRACT}

„Advertising and Administration under the Pressure of Ethics" (2 44) ook of tellectual elevation and high expression of ideas of Professor Sandu Frunză from Babeş-Bo Univ isity (ClujNapoca, Romania), published to a French publisher, Les Arcs, Ed de la Sue re zetetic core (inquiry core) is one of ethical theory and applied ethics. It is an hica ory of the public space and the ethical inflections in the administration, in the advertising and Bio s. Qverall, the book has cohesion and consistency. Therefore, it is a pleasant and ip sructive reading.

Keywords: ethics; communication; ethical responsibility, essure of et] ics

\section{STRUCTURE AND IDEAS}

The volume consists of $1 \%$ chap is of wh 1 , as specification of the author, some were previously published in journa new. Three chapters ("stmima Fthics and New Configurations of Public Space", "Deontological Codes Their Imp in Professional Development and the Shaping of Public Space", Res ct, a Exigen cy in Public Space Action) have a mainly theoretical character and are peed in th seld of theoretical ethics. The other seven unfolds aspects of applied ethics Elen of ap a ded administrative ethics are approached in four chapters: "Administr. Eth es iro n the Perspective of the Rights and Duties in Relation to Oneself", "Administrativ Gics fro the Perspective of the Rights and Duties in Relation to Otherness", "Ethio nagen athics Management in Public Administration ", "Ethics in the $\mathrm{Co}$ uct $\mathrm{O}$ Civil Se ants". The issues of applied ethical advertising are discussed in three chap ong - Between the Suspension of Desire and the Ethics of Seduction", "Ethics the Code of Advertising Practice," "Advertising and Social Responsibility". Two chapters a Cedicated to major issues of Bioethics: "Euthanasia as a Public Debate Topic" and "Abortion as a Topic of Public Debate and Action".

Scientific concepts of constructivist guidance of Sandu Frunză's Professor was configured in researches so far as a three axis: construction, ethical conduct and social responsibility. The first axis of thought that underlying the volume is that reality is constructed. Moreover, it focuses on one of the ideas of irradiating ideas of constructivist thinking of Sandu Frunză's Professor. Constructivism underpins how the reputed specialist design language, communication, social relationships, public space operation, administration, advertising, etc.. Specifically, the constructivism based how is imagined the communication and its role in 
society: "Idea That communication constructs reality" (see Frunză, 2011a). However, "communication constructs reality in the globalized society" (see Frunză, 2011b 2011). Also, mass communication and politics are seen as generating of the symbolic construction of reality "mass media is among others, an instrument of symbolic construction of reality" (Frunză, 2011c).

The second thought axis of the book is the ethics behavior derived in communication ethics.

Finally, the third thought axis is the social responsibility. Recall that in 2011, Mr. Frunza published his great relevance book" Ethics Communication and Social Responcihility" (Bucharest: Tritonic). Related this Cristina-Georgiana Voicu (2011) showed that "revears v ethical and effective communication requirement arises from the need of ssuming personal, community, social and institutional values, beyond any relativism or volutism (The success of this book led to its subsequent publication in 2013 in sermany, p tigi as publishing the LAP Lambert Academic Publishing - Frunză, 2013).

The three constants of the investigation and justification syst $\mathrm{c}$, found so in the book in question. Greater and more consistent than before they lic a drection of convergence. Now it becomes obvious that the ideal cor Sandu Fru a's Professor conception consists of ethical construction of respons flity onstruction of ethical responsibility.

The constructive principle appears both in dvertising approgeh and in the public administration activity. Sandu Frunză states: "In a mmunicatiol-based society, advertising construes reality. Considering the symbolic elemen used by dvertising to bring together immanent and transcendent meanings, we can conclua that communication form best adapted to unity the two worlds. Advertisi has this unification function in the daily reality" (p. 171). The individual, stated, is "a mer ou the community" and "participant to the construction of public space" ( $p$ - 19). The s rting point in the configuration, socialization, education of the individual as sou being as, a member of the community) should be "construction of minima mo " (p 14). Constructive basis of society is an ethical one. Building of a superior soci can the basis of norms, of certain rules, of deontological codes "co truction in ies, among others, an assumption of the articles of the deontological, codes" $\mathrm{p}$.

Optimal po ib ity or vial structuring is represented by the organizations. To better serve individua s components cessary that organizations to be placed on ethical bases; it is talking a t "etb 1 construction of the organization" (p. 39). The ethics construction should be res ible. $B$ ond the ethical level there is the superordinated value of the respon ity.

The unza pr essor considers individual responsibility and a social responsibility. In aaa. no The E. s of Kesponsibility", 2007; Bronwyn Davies, "Re-thinking behavior in terms of positionl ard the ethics of responsibility", 2008), the Sandu Frunză Professor from Cluj advocates $20 \mathrm{r}$ an ethics of responsibility (see section " Towards an Ethics of Responsibility") and states: "Ethical Responsibility cannot be built outside individual option and free personal commitment" (p. 188).

\section{CONCLUSION}

The movement of the investigative thinking is double; also what moves the arguments is a double articulated ethical meditation. On the one hand, reflection is focused on finding 
incidents of the ethics and deontology in terms of advertising and administrative activity. On the other hand, it is directed on reveal of the aspects of the emergence of a new positioning. On the first component is found the incidence of a natural ethic, and on the second is developed as it appears and it is required an ethical, pre-programmed built. Moreover, on this second component catagraphies the articulations of an imposed ethic. It follows that in the advertising and administration, generally in the public space, it is passing from a natural ethic to a required ethic. The natural ethics is strengthened, reinforced, extended by the pressure of a selfconscious ethic, an advanced ethic. From the minimum natural ethics it opens the way to an extended ethic and advanced.

\section{References}

[1] Sandu Frunză (2013). Ethical Communication and Social Respon vility. Academic Publishing.

[2] Sandu Frunza (2011)a. The Relational Individual in a Con nication Towards a New Philosophy of Communication. Transyl anta Seview.

[3] Sandu Frunză (2011)b. Ethical responsibility and ss... respons toporganizations involved in the public health system. Revista de rrcetare şi interve, ţie socială.

[3] Sandu Frunză (2011)c. Does communication co truct reality A new perspective on the crisis of religion and the dialectic of the sacred. rista de ercetare şi intervenţie socială.

[5] Sandu Frunză (2011)d. Media Communi tion Politics of the Symbolic Construction of Reality. Religions and Ide ogies.

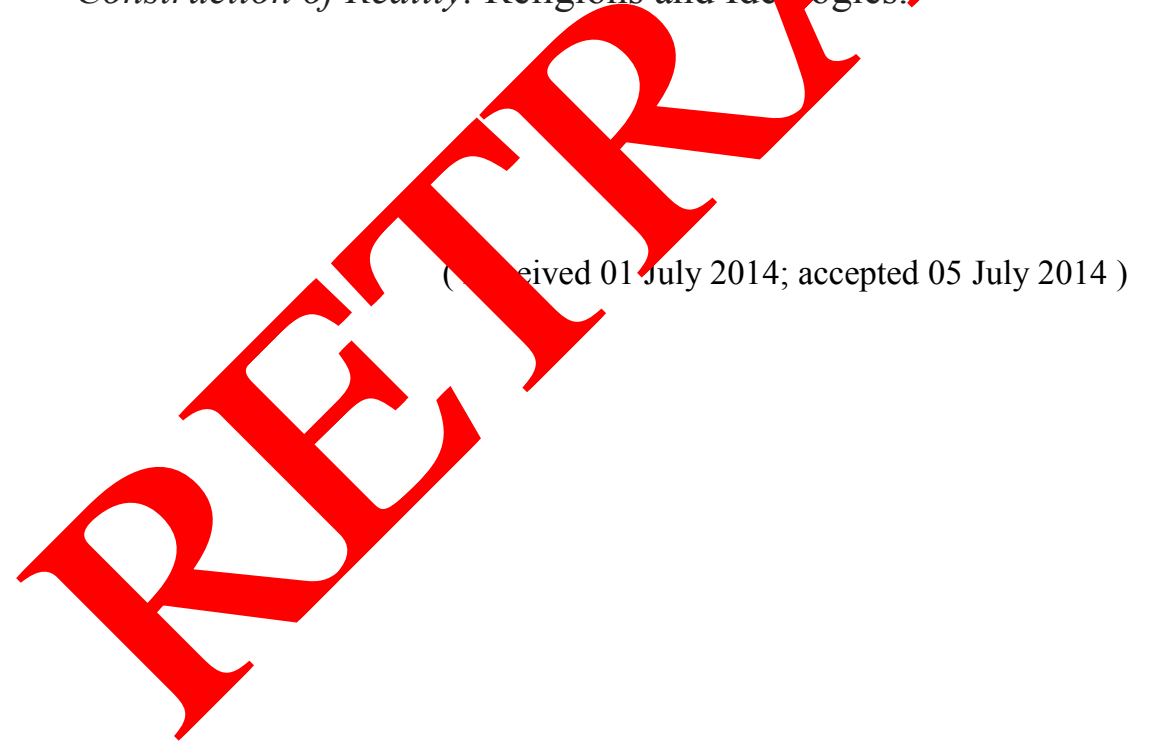

